\title{
Infectivity Titration for Assessing Resistance to Leaf Scald Among Sugarcane Cultivars
}

\author{
S. A. Lopes, Unidade de Biotecnologia, Universidade de Ribeirão Preto, Ribeirão Preto SP 14096-380, Brasil; K. \\ E. Damann and J. W. Hoy, Department of Plant Pathology and Crop Physiology, Louisiana State University Agri- \\ cultural Center, Baton Rouge 70803; and M. P. Grisham, USDA-ARS, Sugarcane Research Unit, Houma, LA \\ 70361
}

\begin{abstract}
Lopes, S. A., Damann, K. E., Hoy, J. W., and Grisham, M. P. 2001. Infectivity titration for assessing resistance to leaf scald among sugarcane cultivars. Plant Dis. 85:592-596.

Greenhouse experiments were conducted to determine potential of infectivity titration to evaluate resistance of sugarcane to leaf scald disease caused by Xanthomonas albilineans. In two experiments, single-bud cuttings were inoculated with suspensions containing $10^{1}, 10^{5}$, or $10^{8}$ $\mathrm{CFU} / \mathrm{ml}$ of $X$. albilineans. The occurrence of symptoms was recorded every 15 days from 45 to 210 days after inoculation. At the final evaluation date, leaf vascular sap was plated onto selective medium to detect latent infections. $\mathrm{ED}_{50}\left(\log _{10}\right.$ of the bacterial concentration required to infect $50 \%$ of inoculated plants) was estimated for each cultivar based on probit analysis of cumulative infection frequency. Frequency of infected plants varied among inoculum doses and cultivars and resulted in $\mathrm{ED}_{50}$ values ranging from 3.0 to 12.3 and 3.1 to 9.8 in the first and second experiments, respectively. Good agreement between experiments was observed for $\mathrm{ED}_{50}$ values of individual cultivars. Differences in $\mathrm{ED}_{50}$ among cultivars agreed with field observations of natural disease incidence. Cultivar responses to leaf scald were compared based on the cumulative frequencies of death and recovery in symptomatic plants, and the frequencies of symptomatic plants observed at different evaluation dates for plants inoculated with $10^{8} \mathrm{CFU} / \mathrm{ml}$ of $X$. albilineans. Good agreement between $\mathrm{ED}_{50}$ values and these responses was observed. Greenhouse inoculation tests using infectivity titration or just one inoculum concentration could provide an alternative to field tests for the assessment of sugarcane resistance to leaf scald.
\end{abstract}

Additional keyword: Saccharum

Leaf scald, caused by Xanthomonas albilineans (Ashby) Dowson, is a potentially severe disease of sugarcane (interspecific hybrids of Saccharum L.) (17). The pathogen colonizes the xylem and may or may not induce visible symptoms in infected plants. When present, symptoms range from white leaf stripes or bleaching to extensive leaf necrosis, which may result in death of shoots or entire plants of susceptible cultivars $(10,17)$. Symptom expression and severity are associated with the level of cultivar resistance, environmental conditions, and pathogen aggressiveness. Severe losses to leaf scald occurred early in this century on susceptible "noble canes" derived from Saccharum officinarum L. The introduction of more resistant hybrid cultivars, produced from crosses involving $S$. spontaneum L., brought the disease under control (17). However, the continued rapid spread of leaf scald throughout the sugarcane growing regions of the world, and the occur-

Corresponding author: K. E. Damann

E-mail:kdamann@agctr.lsu.edu

Accepted for publication 2 January 2001.

Publication no. D-2001-0326-01R

(c) 2001 The American Phytopathological Society rence of periodic outbreaks in areas where the disease was assumed to be under control, have caused concern.

In the continental United States, leaf scald was first detected in Florida in 1967 (14) and in Louisiana in 1992 (8). In Florida, the disease remained very limited in distribution until the late 1980s, when it spread rapidly through sugarcane producing areas (1). In Louisiana, a field survey was undertaken soon after its detection to determine the distribution of the disease in the state and to evaluate the response of commercial cultivars (10). Leaf scald was found in all sugarcane producing areas with a range of incidence and severity depending on the cultivar. The cultivars $\mathrm{CP}$ 74-383 and LCP 82-89 were the most affected in terms of incidence and severity. Since planting resistant cultivars is the most effective method of control $(4,17)$, the objective of this study was to determine if a greenhouse inoculation test, using infectivity titration, would be useful to accurately assess the resistance of promising sugarcane clones developed by breeding programs. Infectivity titration has been used in other pathosystems (5), and to test sugarcane resistance against the ratoon stunting disease (RSD) pathogen, Clavibacter xyli subsp. xyli (9). Preliminary results of this research have been reported (15).

\section{MATERIALS AND METHODS}

Source of sugarcane. In the first experiment, stalks of 13 cultivars (L 62-96, CP 65-357, CP 70-321, CP 72-370, CP 74383, CP 79-318, LCP 82-89, LHo 83-153, LCP 85-384, HoCP 85-845, LCP 86-454, CP 88-739, L 88-63) were collected from plants derived from meristem culture and grown at the Louisiana State University Agricultural Center Experiment Station at St. Gabriel, the USDA-ARS Sugarcane Research Unit in Houma, and a commercial seedcane farm in Theriot, LA. In the second experiment, L 62-96, HoCP 85-845, L 88-63, and CP 88-739 were not included. The basal internode of each stalk was assayed for RSD by alkaline-induced metaxylem autofluorescence (2) of stem cross sections, and confirmed by dark-field microscopic observation of centrifuged plant sap (7) for the presence of $C$. xyli subsp. xyli. Approximately 120 single-bud cuttings, $4 \mathrm{~cm}$ long, were cut from RSDfree stalks of each cultivar for inoculation.

Inoculum preparation. $X$. albilineans was isolated from cultivar LCP 82-89 as previously described (16). A leaf showing symptoms of leaf scald was washed thoroughly with tap water and dried with a paper towel. Segments approximately $1 \mathrm{~cm}$ in length were excised from longitudinal white stripes, transferred to a microscope slide containing sterile water, and observed under a dissecting microscope for exudate containing bacteria. Plant tissue exudate was collected with a Pasteur pipet, transferred to a semi-selective medium (3), and incubated for 5 days. An individual colony, designated XaIT, was transferred to a 500$\mathrm{ml}$ flask containing $250 \mathrm{ml}$ of Wilbrink's broth (17) and grown in shake culture for 3 days at room temperature. Just before inoculation, the broth culture was serially diluted in $1.5 \mathrm{ml}$ microfuge tubes, spread on Wilbrink's agar and incubated for 5 days at $28^{\circ} \mathrm{C}$ to estimate inoculum concentration. Dilutions used as inoculum contained approximately $10^{1}, 10^{5}$, or $10^{8}$ $\mathrm{CFU} / \mathrm{ml}$. Isolate $\mathrm{Xa}$ IT was used in both experiments.

Inoculation. Single-bud cuttings of each cultivar were immersed in 1 liter of each inoculum suspension in plastic ziplock bags. After $1 \mathrm{~h}$ at room temperature, the inoculum was removed and the bags were sealed and maintained overnight at room temperature (9). The next day, the cuttings 
were planted in 32-well styrofoam trays containing Jiffy-Mix Plus (Jiffy Products of America, Batavia, IL) and maintained under greenhouse conditions. The plants were watered regularly and fertilized $(\mathrm{N}=$ $15 \%, \mathrm{P}=30 \%, \mathrm{~K}=15 \%, 2.6 \mathrm{~g}$ per liter) when symptoms of mineral deficiency, as indicated by general leaf chlorosis, were observed.

Disease assessment and analysis. Sugarcane plants were observed for white leaf stripes every 15 days, 45 to 210 days after inoculation. The position of each symptomatic plant in the tray was marked on a map at each evaluation date. Symptomatic plants were maintained in the trays. At the last evaluation, leaf samples were collected for assessing latent infections. All nonsenescent leaves were excised from each plant using a knife sterilized in $95 \%$ ethanol and flamed. Sections $2.5 \mathrm{~cm}$ in length from these leaves were packed tightly into 1.5-ml microfuge tubes (6) and kept on ice. The tubes were centrifuged at $8,000 \times \mathrm{g}$ for $3 \mathrm{~min}$ in a microfuge or a DuPont-Sorval RC5B centrifuge (DuPont, Newtown, CT) using the SH-MT rotor for $1.5 \mathrm{ml}$ tubes.
Sterile tweezers were used to remove leaf segments from the tubes. Sap volumes of approximately $20 \mu \mathrm{l}$ were collected from each sample and plated on a semi-selective medium (3) using sterile wood toothpicks. Plates were maintained at $28^{\circ} \mathrm{C}$ and observed after 7 days for the presence of small, light yellow and nonmucoidal colonies typical of $X$. albilineans. The cumulative frequency of infection (total number of symptomatic plants plus latent infections) were analyzed using the probit procedure of SAS (Statistical Analysis System, Cary, $\mathrm{NC})$ to estimate $\mathrm{ED}_{50}$ values $\left(\log _{10}\right.$ of the bacterial concentration required to infect $50 \%$ of the inoculated plants) (5) for each cultivar.

Cultivar response to leaf scald was also measured based on the cumulative frequency of death or recovery in symptomatic plants at all three inoculum concentrations, and on the cumulative frequencies of symptomatic plants inoculated with $10^{8} \mathrm{CFU} / \mathrm{ml}$ of $X$. albilineans recorded at each evaluation date. Plants were considered recovered from leaf scald disease if no white stripes were evident from 150 to

Table 1. Cumulative frequency of leaf scald in sugarcane plants derived from single-bud cuttings inoculated with three concentrationsof Xanthomonas albilineans, as determined by symptom observations and pathogen isolation 210 days after inoculation

\begin{tabular}{|c|c|c|c|c|c|c|}
\hline \multirow[b]{2}{*}{ Cultivar } & \multicolumn{3}{|c|}{$\begin{array}{c}\text { First experiment } \\
\text { Inoculum concentration } \\
\left(\log _{10} \mathrm{CFU} / \mathrm{ml}\right)\end{array}$} & \multicolumn{3}{|c|}{$\begin{array}{c}\text { Second experiment } \\
\text { Inoculum concentration } \\
\left(\log _{10} \mathrm{CFU} / \mathrm{ml}\right)\end{array}$} \\
\hline & 1 & 5 & 8 & 1 & 5 & 8 \\
\hline НоСР 85-845 & $0 / 32$ & $31 / 32$ & $31 / 32$ & n.t. ${ }^{a}$ & n. t. & n.t. \\
\hline CP 74-383 & $0 / 31$ & $29 / 31$ & $24 / 24$ & $2 / 23$ & $18 / 22$ & $22 / 23$ \\
\hline LCP $82-89$ & $0 / 20$ & $16 / 25$ & $23 / 24$ & $7 / 32$ & $29 / 32$ & $32 / 32$ \\
\hline CP 72-370 & $1 / 32$ & $12 / 30$ & $29 / 31$ & $1 / 32$ & $17 / 32$ & $21 / 32$ \\
\hline L 62-96 & $3 / 28$ & $13 / 25$ & $18 / 29$ & n.t. & n.t. & n.t. \\
\hline СР 70-321 & $0 / 31$ & $17 / 30$ & $16 / 32$ & $5 / 32$ & $17 / 32$ & $18 / 32$ \\
\hline LCP 86-454 & $0 / 25$ & $9 / 29$ & $12 / 29$ & $0 / 32$ & $12 / 27$ & $26 / 32$ \\
\hline СР 88-739 & $0 / 32$ & $9 / 32$ & $12 / 32$ & n.t. & n.t. & n.t. \\
\hline LHo 83-153 & $2 / 29$ & $7 / 30$ & $12 / 30$ & $0 / 32$ & $3 / 32$ & $20 / 32$ \\
\hline CP 65-357 & $0 / 32$ & $5 / 32$ & $6 / 32$ & $3 / 32$ & $8 / 32$ & $19 / 32$ \\
\hline CP 79-318 & $1 / 31$ & $3 / 28$ & $9 / 31$ & $1 / 32$ & $8 / 31$ & $12 / 31$ \\
\hline L 88-63 & $1 / 32$ & $4 / 31$ & $10 / 32$ & n.t. & n.t. & n.t. \\
\hline LCP 85-384 & $0 / 32$ & $1 / 32$ & $3 / 32$ & $0 / 32$ & $3 / 32$ & $6 / 32$ \\
\hline
\end{tabular}

${ }^{\mathrm{a}}$ n.t. $=$ not tested.

Table 2. $\mathrm{ED}_{50}$ ( $\log _{10}$ of the bacterial concentration required to infect $50 \%$ of inoculated plants) determined by probit analysis of cumulative frequencies of infected sugarcane plants, inoculated with three concentrations of Xanthomonas albilineans in two experiments

\begin{tabular}{|c|c|c|c|c|c|c|c|}
\hline \multirow[b]{2}{*}{ Cultivar } & \multicolumn{3}{|c|}{ First experiment } & \multicolumn{3}{|c|}{ Second experiment } & \multirow[b]{2}{*}{ Mean $\mathbf{E D}_{\mathbf{5 0}}$} \\
\hline & $\begin{array}{c}\mathbf{E D}_{50}(\mathbf{9 5 \%} \text { fidu- } \\
\text { cial limits) }\end{array}$ & $\begin{array}{c}\text { Regression } \\
\text { equation }\end{array}$ & $P>$ Chi-square & $\begin{array}{l}\mathbf{E D}_{50}(95 \% \text { fidu- } \\
\text { cial limits })\end{array}$ & $\begin{array}{c}\text { Regression } \\
\text { equation }\end{array}$ & $P>$ Chi-square & \\
\hline НоCP 85-845 & $3.0(2.3,3.7)$ & $Y=-2.2+0.73 X$ & 0.0001 & n.t. ${ }^{\mathrm{b}}$ & n.t. & n.t. & 3.0 \\
\hline CP $74-383$ & $3.2(2.4,3.9)$ & $Y=-3.2+0.98 X$ & 0.0001 & $3.1(1.4,4.3)$ & $Y=-1.3+0.43 X$ & 0.0001 & 3.2 \\
\hline LCP $82-89$ & $3.9(2.9,4.8)$ & $Y=-2.3+0.59 X$ & 0.0001 & $4.4(\ldots)$ & $Y=-8.6+1.94 X$ & 0.9998 & 4.2 \\
\hline CP 72-370 & $5.5(4.5,6.2)$ & $Y=-3.3+0.60 X$ & 0.0001 & $4.7(0.9,5.6)$ & $Y=-2.4+0.51 X$ & 0.0066 & 5.1 \\
\hline L 62-96 & $5.2(1.9,7.6)$ & $Y=-1.0+0.20 X$ & 0.0005 & n.t. & n.t. & n.t. & 5.2 \\
\hline СР 70-321 & $5.4(3.8,7.1)$ & $Y=-1.3+0.24 X$ & 0.0001 & $5.4(0.2,9.6)$ & $Y=-0.7+0.14 X$ & 0.0043 & 5.4 \\
\hline LCP $86-454$ & $6.8(5.2,9.4)$ & $Y=-1.7+0.24 X$ & 0.0002 & $5.3(4.2,6.4)$ & $Y=-2.0+0.15 X$ & 0.0001 & 6.1 \\
\hline СР 88-739 & $7.1(5.6,9.5)$ & $Y=-1.7+0.24 X$ & 0.0001 & n.t. & n.t. & n.t. & 7.1 \\
\hline LHo 83-153 & $9.2(5.3,24.6)$ & $Y=-1.5+0.16 X$ & 0.0287 & $7.0(6.0,8.4)$ & $Y=-2.7+0.38 X$ & 0.0001 & 8.1 \\
\hline CP $65-357$ & $10.0(7.3,24.1)$ & $Y=-1.6+0.16 X$ & 0.0082 & $7.5(5.6,9.8)$ & $Y=-2.8+0.37 X$ & 0.0169 & 8.8 \\
\hline CP 79-318 & $9.6(\ldots)^{\mathrm{a}}$ & $Y=-3.1+0.32 X$ & 0.0914 & $8.2(5.9,13.0)$ & $Y=-1.5+0.18 X$ & 0.0016 & 8.9 \\
\hline L 88-63 & $10.3(\ldots)$ & $Y=-2.3+0.22 X$ & 0.2155 & n.t. & n.t. & n.t. & 10.3 \\
\hline LCP 85-384 & $12.3(8.8,59.3)$ & $Y=-2.0+0.16 X$ & 0.0256 & $9.8(7.5,19.0)$ & $Y=-1.9+0.19 X$ & 0.0038 & 11.0 \\
\hline
\end{tabular}

a $95 \%$ fiducial limits not estimated by the SAS statistical program.

${ }^{\mathrm{b}}$ n.t. $=$ not tested. 
cated that for most cultivars the probability of response increased significantly as the inoculum concentration increased. In no case did the slope of the regression line reach 2.0. This indicates $X$. albilineans cells acted independently to infect the inoculated sugarcane cuttings (5). Based on the mean $\mathrm{ED}_{50}$ values (Table 2), the cultivars may be ranked in decreasing levels of resistance as follows: LCP 85-384, L 8863, CP 79-318, CP 65-357, LHo 83-153, CP 88-739, LCP 86-454, CP 70-321, L 6296, CP 72-370, LCP 82-89, CP 74-383, HoCP 85-845.

Cultivar response to leaf scald also was compared based on the cumulative frequencies of death or recovery in sympto- matic plants (Table 3 ). For cultivars $\mathrm{CP}$ 74-383 and LCP $82-89$, over $50 \%$ of the symptomatic plants were killed by $X$. albilineans in the first and second experiments, and no plant recovered from leaf symptoms. For cultivars CP 65-357, CP 70-321, CP 72-370, CP 79-318, CP 88-739, L 62-96, L 88-63, LCP 85-384, HoCP 85-845, LCP 86-454, and LHo 83153 , no symptomatic plants were killed by $X$. albilineans in the first experiment, but $9 \%$ and $4 \%$ of the symptomatic plants of CP 70-321 and CP 65-357, respectively, died in the second experiment. The frequency of recovery for these cultivars ranged from 2 (LCP 85-845) to $91 \%$ (CP 79-318) in the first, and from 6 (CP 72-
$370)$ to $87 \%$ (CP 65-357) in the second experiment.

$\mathrm{ED}_{50}$ values for cultivars were highly correlated in both experiments (Table 4). In the first experiment, significant correlation was observed between $\mathrm{ED}_{50}$ and the cumulative frequency of dead plants recorded during the entire period the experiment was conducted, and between $\mathrm{ED}_{50}$ and the cumulative frequency of symptomatic plants inoculated with $10^{8} \mathrm{CFU} / \mathrm{ml}$ of $X$. albilineans recorded from 90 to 210 days after inoculation. In the second experiment, significant correlation was observed between $\mathrm{ED}_{50}$ and cumulative frequencies of death and recovery in symptomatic plants, recorded during the entire period the ex-

Table 3. Cumulative frequencies of symptomatic plants killed by leaf scald disease or recovered from symptoms at the end of the experiment 210 days after inoculations

\begin{tabular}{|c|c|c|c|c|c|c|c|c|c|c|}
\hline & \multicolumn{5}{|c|}{ First experiment } & \multicolumn{5}{|c|}{ Second experiment } \\
\hline & Total & Dead & $\%$ & Recovery & $\%$ & Total & Dead & $\%$ & Recovery & $\%$ \\
\hline НоСР 85-845 & 45 & 1 & 2 & 1 & 2 & n.t. ${ }^{a}$ & n.t. & n.t. & n.t. & n.t. \\
\hline CP 74-383 & 60 & 31 & 52 & 0 & 0 & 38 & 31 & 82 & 0 & 0 \\
\hline LCP $82-89$ & 39 & 25 & 64 & 0 & 0 & 57 & 40 & 70 & 0 & 0 \\
\hline CP 72-370 & 32 & 2 & 6 & 2 & 6 & 31 & 2 & 6 & 2 & 6 \\
\hline L 62-96 & 26 & 0 & 0 & 19 & 73 & n.t. & n.t. & n.t. & n.t. & n.t. \\
\hline CP 70-321 & 20 & 0 & 0 & 1 & 5 & 34 & 3 & 9 & 9 & 26 \\
\hline LCP 86-454 & 11 & 0 & 0 & 0 & 0 & 11 & 0 & 0 & 0 & 0 \\
\hline СР 88-739 & 13 & 0 & 0 & 5 & 38 & n.t. & n.t. & n.t. & n.t. & n.t. \\
\hline LHo83-153 & 19 & 0 & 0 & 13 & 68 & 23 & 0 & 0 & 18 & 78 \\
\hline СР 65-357 & 11 & 0 & 0 & 2 & 18 & 23 & 1 & 4 & 20 & 87 \\
\hline CP 79-318 & 11 & 0 & 0 & 10 & 91 & 16 & 0 & 0 & 9 & 56 \\
\hline L 88-63 & 7 & 0 & 0 & 1 & 14 & n.t. & n.t. & n.t. & n.t. & n.t. \\
\hline LCP 85-384 & 1 & 0 & 0 & 0 & 0 & 13 & 0 & 0 & 5 & 38 \\
\hline
\end{tabular}

a n.t. $=$ not tested.

Table 4. Correlation of $\mathrm{ED}_{50}$ values with cumulative frequencies of death and recovery, and of frequencies of symptomatic plants at different evaluation dates in plants inoculated with the highest concentration of Xanthomonas albilineans

\begin{tabular}{|c|c|c|c|c|}
\hline \multirow[b]{2}{*}{ Parameters } & \multirow[b]{2}{*}{ Experiment } & \multicolumn{3}{|c|}{ Coefficient of correlation ${ }^{a}$} \\
\hline & & ED $_{50} 1^{\text {st }}$ experiment & ED $_{50} 2^{\text {nd }}$ experiment & Mean ED $\mathbf{5 0}_{\mathbf{0}}$ \\
\hline \multirow[t]{2}{*}{$\mathrm{ED}_{50}{ }^{\mathrm{b}}$} & First & 1.00 & $0.96 * *$ & $1.00 * *$ \\
\hline & Second & $0.96^{* *}$ & 1.00 & $0.98 * *$ \\
\hline \multirow[t]{2}{*}{ Recovery frequency ${ }^{\mathrm{c}}$} & First & 0.46 & 0.46 & 0.47 \\
\hline & Second & $0.77 * *$ & $0.71 *$ & $0.76^{* *}$ \\
\hline \multirow[t]{2}{*}{ Death frequency } & First & $-0.76 * *$ & $-0.66^{*}$ & $-0.74 * *$ \\
\hline & Second & $-0.79 * *$ & $-0.69 *$ & $-0.77 * *$ \\
\hline \multirow[t]{3}{*}{ Cumulative frequency of symptomatic plants 60 days after inoculation } & First & -0.59 & -0.51 & $-0.58 *$ \\
\hline & Second & -0.33 & -0.36 & -0.33 \\
\hline & Mean & -0.52 & -0.50 & -0.52 \\
\hline \multirow[t]{3}{*}{ Cumulative frequency of symptomatic plants 90 days after inoculation } & First & $-0.73^{*}$ & $-0.63 *$ & $-0.71 *$ \\
\hline & Second & -0.43 & -0.46 & -0.44 \\
\hline & Mean & -0.62 & -0.59 & -0.62 \\
\hline \multirow[t]{3}{*}{ Cumulative frequency of symptomatic plants 120 days after inoculation } & First & $-0.74 *$ & $-0.63^{*}$ & $-0.72 *$ \\
\hline & Second & -0.61 & -0.62 & -0.61 \\
\hline & Mean & $-0.69 *$ & $-0.64 *$ & $-0.68 *$ \\
\hline \multirow[t]{3}{*}{ Cumulative frequency of symptomatic plants 150 days after inoculation } & First & $-0.77 * *$ & $-0.70 *$ & $-0.76^{* *}$ \\
\hline & Second & $-0.66^{*}$ & $-0.68 *$ & $-0.66^{*}$ \\
\hline & Mean & $-0.76^{* *}$ & $-0.72 *$ & $-0.75^{*}$ \\
\hline \multirow[t]{3}{*}{ Cumulative frequency of symptomatic plants 180 days after inoculation } & First & $-0.83^{* *}$ & $-0.76^{* *}$ & $-0.82 * *$ \\
\hline & Second & $-0.68 *$ & $-0.71 *$ & $-0.69 *$ \\
\hline & Mean & $-0.81 * *$ & $-0.77 * *$ & $-0.80^{* *}$ \\
\hline \multirow{4}{*}{$\begin{array}{l}\text { Cumulative frequency of symptomatic plants and latent infections } 210 \\
\text { days after inoculation }^{\mathrm{d}}\end{array}$} & & & & \\
\hline & First & $-0.89 * *$ & $-0.84 * *$ & $-0.88 * *$ \\
\hline & Second & $-0.69 *$ & $-0.73^{*}$ & $-0.70^{*}$ \\
\hline & Mean & $-0.83^{* *}$ & $-0.83^{* *}$ & $-0.84 * *$ \\
\hline
\end{tabular}

${ }^{a}$ Some coefficients were significant at $95 \%(*)$ and $99 \%(* *)$ levels of probability.

${ }^{\mathrm{b}} \mathrm{ED}_{50}$, effective dose, or inoculum concentration necessary to cause disease in $50 \%$ of the plants, estimated based on cumulative frequencies of infected plants inoculated with $10^{1}, 10^{5}$, or $10^{8} \mathrm{CFU} / \mathrm{ml}$ of $X$. albilineans.

c Plants not showing leaf scald symptoms (white leaf stripes) from 150 days after inoculation to the end of the experiment.

${ }^{\mathrm{d}}$ Latent infections were determined by pathogen isolation from asymptomatic plants. 
periment was conducted, and between $\mathrm{ED}_{50}$ and the cumulative frequency of symptomatic plants, recorded from 150 to 210 days after inoculation.

\section{DISCUSSION}

Traditionally, tests of sugarcane cultivar response to leaf scald have been conducted under field conditions with the decapitation inoculation method $(4,12,13,18,21,22)$. This method contains uncontrolled variables that may affect the results. In some cases, the inoculum consists of juice obtained by crushing severely infected sugarcane stalks with no estimation of inoculum concentration. Different inoculum concentrations may result in different plant responses and/or frequency of infections, as demonstrated in this work, especially for the susceptible and resistant cultivars. Another problem is associated with the quality of the inoculum used, as pointed out by Valdebenito and Tokeshi (20). Vascular bundles of leaf scald-infected sugarcane plants were found to harbor a mixture of bacterial species (19). These bacteria could interact with $X$. albilineans, interfering with the process of plant infection and disease development (20). Finally, inoculated plant surfaces are exposed to environmental conditions that vary between experiments.

The use of the decapitation inoculation method to assess leaf scald resistance has not always produced results that match field reactions to leaf scald. In experiments in Australia with 15 cultivars of known field reaction under natural conditions, differences in clone reactions occurred between trials, which were attributed to variable weather conditions (4). It was impossible to separate the intermediate and susceptible groups of cultivars, and one cultivar, which was resistant in the field under natural conditions, was rated as intermediate (4). Leaf scald symptom expression in cultivars in inoculated tests conducted in the field under Louisiana conditions also has been variable (M. P. Grisham and J. W. Hoy, unpublished data). In ten experiments conducted between 1993 and 2000 using the decapitation method to determine susceptibility of breeding clones to leaf scald, inoculation was unsuccessful in four.

The cultivars (11 or 12 of the 13) tested in this study, using infectivity titration, were tested in two field experiments using the decapitation method (M. P. Grisham, unpublished). The reactions of CP 65-357 in the field experiments did not agree with the results of the infectivity titration experiments. CP 65-357 was among the most susceptible in the field experiments while ranking tenth most susceptible (Table 2) in the infectivity titration experiments. Cultivar response-year interaction also was observed in the field experiments. For example, CP 70-321 ranked second, sixth, and seventh most susceptible, and CP 74-
383 ranked first, third, and fifth most susceptible among the three field experiments. These results indicate the need for an alternative method to assess cultivar responses to leaf scald that would be more consistent and reliable.

Here we show that the response of sugarcane to the leaf scald pathogen can be assessed by infectivity titration experiments carried out under greenhouse conditions. The fiducial limits indicated that the precision of the estimated $\mathrm{ED}_{50}$ values varied among cultivars. Precision was poor when estimated values were above the range of inoculum concentrations used, as would be expected. Nevertheless, good agreement among $\mathrm{ED}_{50}$ values between experiments was observed. Good agreement between $\mathrm{ED}_{50}$ and cumulative frequency of death and recoveries in symptomatic plants also was shown. Concentrations of approximately $10^{3}$ to $10^{4}$ $\mathrm{CFU} / \mathrm{ml}$ of $X$. albilineans would be sufficient to infect $50 \%$ of the plants of the susceptible cultivars, such as CP 74-383 and LCP 82-89. Furthermore, 52 to $82 \%$ of the symptomatic plants of these cultivars were killed. The most resistant cultivars (LCP 85-384, L 88-63, CP 79-318, CP 65357, and LHo 83-153) would have required a higher concentration of bacterial cells (by $10^{4}$ to $10^{8} \mathrm{CFU} / \mathrm{ml}$ ) for $50 \%$ infection, than would be required for susceptible cultivars. In addition, most symptomatic plants of resistant cultivars recovered from symptoms. HoCP 85-845 was an exception. It had a low estimated $\mathrm{ED}_{50}$ value, but diseased plants were not killed by the pathogen. At the same time, no recovery was detected. These results suggest HoCP 85845 may be tolerant to leaf scald.

The experiments were carried out in foam trays with the plants grown close to each other, and symptomatic plants were maintained until the last evaluation, when leaf samples were collected and processed for pathogen isolation. The prolonged, close proximity of diseased and healthy plants in the trays could have resulted in natural spread of leaf scald during watering, caused by bacterial cells that exude from infected leaves (11). None of the plants of susceptible or highly susceptible cultivars in another study, however, were colonized nor developed leaf scald symptoms when a suspension of $10^{8} \mathrm{CFU} / \mathrm{ml}$ of $X$. albilineans was sprayed on sugarcane leaves or when young tissue culture derived plants or cuttings were planted in $X$. albilineans infested soil (11). In addition, any natural disease spread in the infectivity titration experiments would have been minimized by maintaining cultivars in different trays and separating the different inoculum concentrations. Even if some natural spread of leaf scald occurred, differences in resistance among cultivars were clearly identified.

The results of this study are in agreement with the results of a survey conducted shortly after the appearance or leaf scald in Louisiana to determine the geographic distribution, incidence, and severity of leaf scald in naturally infected sugarcane fields (10). In that survey, leaf scald was most widely distributed in cultivars CP 74-383 and LCP 82-89, which were also the most affected by the disease in terms of incidence and severity. In a field of droughtstressed CP 74-383, extensive plant death and severe losses were observed. HoCP 85 845 was released in 1993, and infected plants were found in 11 out of 55 seedcane fields surveyed. Leaf scald symptoms were not observed in any fields of LCP 85-384 at the same locations. In CP 70-321, CP 72-370, and LHo 83-153 the disease was less widely distributed, and low disease incidence was found in fields. Leaf scald was not observed in fields of CP 65-357. In the years after this study (10), the cultivation of CP 74-383 was discontinued, high incidence of disease occurred in LCP 8289 and HoCP 85-845, and the extensive occurrence of severe symptoms including plant death has been observed in LCP 8289 but not in HoCP 85-845 (Grisham and Hoy, unpublished data). LCP 85-384 is now widely cultivated without exhibiting leaf scald symptoms.

Altogether these results indicate that infectivity titration conducted in the greenhouse may provide a reliable alternative to the decapitation inoculation method to assess the resistance of sugarcane clones to leaf scald disease. The $\mathrm{ED}_{50}$ values, and also the frequencies of death and recovery in symptomatic plants, gave good agreement with observed cultivar responses under natural conditions.

The same clone rankings were obtained with cumulative frequencies of symptomatic plants at the highest inoculum concentration $\left(10^{8} \mathrm{CFU} / \mathrm{ml}\right)$, as early as 150 days after inoculation. This suggests that the use of one inoculum concentration, with evaluations based only on symptom expression, would be sufficient to assess cultivar resistance. The use of only one inoculum concentration and evaluation procedure would simplify the technique and allow a larger number of cultivars to be tested. This would be a useful technique for the routine assessment of clone reactions determined as part of a cultivar selection program.

\section{ACKNOWLEDGMENTS}

We thank C. A. Clark, from the Department of Plant Pathology and Crop Physiology, LSU, for his helpful criticism in the preparation of the manuscript, and R. Macchiavelli, from the Department of Experimental Statistics, LSU, for help with the probit analysis. S. A. Lopes was supported by a graduate fellowship from Conselho Nacional de Desenvolvimento Científico e Tecnológico $(\mathrm{CNPq})$, Brazil.

\section{LITERATURE CITED}

1. Comstock, J. C. , and Shine, J. M., Jr. 1992. Outbreak of leaf scald of sugarcane, caused by Xanthomonas albilineans, in Florida. Plant 
Dis. 76:426.

2. Damann, K. E., Jr. 1988. Alkaline-induced metaxylem autofluorescence: A diagnostic symptom of ratoon stunting disease of sugarcane. Phytopathology 78:233-237.

3. Davis, M. J., Rott, P., Baudin, P., and Dean, J. L. 1994. Evaluation of selective media and immunoassays for detection of Xanthomonas albilineans, causal agent of sugarcane leaf scald disease. Plant Dis. 78:78-82.

4. Egan, B.T. 1969. Evaluation of the aluminum cap method for leaf scald disease resistance testing in Queensland. Proc. Int. Soc. Sugar Cane Technol. 13:1153-1158.

5. Ercolani, G. L. 1984. Infectivity titration with bacterial plant pathogens. Annu. Rev. Phytopathol. 22:35-52

6. Gillaspie, A. G., Jr. 1987. Method for detecting Clavibacter xyli subsp. xyli from sugarcane leaves. Plant Dis. 71:691-693.

7. Gillaspie, A. G., Jr., Davis, R. E., and Worley J. F. 1973. Diagnosis of ratoon stunting disease based on the presence of a specific microorganism. Plant Dis. Rep. 57:987-990.

8. Grisham, M. P., Legendre, B. L., and Comstock, J. C. 1993. First report of leaf scald, caused by Xanthomonas albilineans, of sugarcane in Louisiana. Plant Dis. 77:537.

9. Harrison, N. A., Davis, M. J., and Dean, J. L.
1986. Infectivity titrations of Clavibacter xyli subsp. xyli and sugarcane cultivars differing in susceptibility to ratoon stunting disease. Plant Dis. 70:556-558.

10. Hoy, J. W., and Grisham, M. P. 1994. Sugarcane leaf scald distribution, syptomatology, and effect on yield in Louisiana. Plant Dis. 78:1083-1087.

11. Klett, P., and Rott, P. 1994. Inoculum sources for the spread of leaf scald disease of sugarcane caused by Xanthomonas albilineans in Guadeloupe. J. Phytopathology 142:283-291.

12. Koike, H. 1965. The aluminum-cap method for testing sugarcane varieties against leaf scald disease. Phytopathology 55:317-319.

13. Koike, H. 1972. Testing sugarcane varieties for leaf scald disease resistance. Proc. Int. Soc. Sugar Cane Technol. 14:909-919.

14. Koike, H. 1978. Leaf scald of sugarcane in continental United States-A first report. Plant Dis. Rep. 52:646-649.

15. Lopes, S. A., Damann, K. E., Hoy, J. W., and Grisham, M. P. 1995. Infectivity titration for assessing resistance to leaf scald among sugarcane cultivars. (Abstract) Phytopathology $85: 1121$.

16. Masuda, Y., and Tokeshi, H. 1978. A useful method for diagnosis and isolation of Xan- thomonas albilineans (Ashby) Dowson, causal agent of leaf scald in sugarcane. Sug arcane Pathol. Newsl. 20:22-23.

17. Ricaud C., and Ryan, C. C. 1989. Leaf scald Pages 39-58 in Diseases of Sugarcane: Major Diseases. C. Ricaud, B. T. Egan, A. G. Gillaspie, Jr., and C. G. Hughes, eds. Elsevier Science Publishing. New York.

18. Ryan, C. C., Hogarth, D. M., and Croft, B. J. 1980. Leaf scald ratings of foreign and commercial varieties in Queensland. Sugarcane Pathol. Newsl. 24:16-18.

19. Valdebenito, R. M., and Tokeshi, H. 1981. Flora bacteriana em cana-de-açúcar com e sem inoculação de Xanthomonas albilineans. Bras. Açucareiro 98:33-37.

20. Valdebenito-Sanhueza, R. M., and Tokeshi, H. 1985. Relação entre Xanthomonas albilineans, Erwinia herbicola e Pseudomonas spp. em cana-de-açúcar. Summa Phytopathol. 11:105-114.

21. Wismer, C. A. 1969. Methods for testing the resistance of sugarcane to disease. (6) Leaf scald. Sugarcane Pathol. Newsl. 2:24-25.

22. Wismer, C. A., and Koike, H. 1967. Testing sugarcane varieties against eye spot, brown spot, red rot, and leaf scald diseases in Hawaii. Proc. Int. Soc. Sugar Cane Technol. 12:1144-1153. 